\title{
Encyclopedia
}

\section{Tectonic Evolution Review of the East China Sea Basin}

Created by: Bing Wang

Revised by: Nicole Yin, Amber Yao

check for

Version received: 12 November 2019

updates

The back-arc East China Sea Basin lies on extended continental crust at the leading edge of the Eurasian plate. Geology over the East China Sea Shelf Basin have been studied bits and pieces by various researchers over the past 20 years. This work is intended to provide a full review of the tectonic evolution over the East China Sea Basin.

\section{Introduction}

The East China Sea contains the largest Mesozoic-Cenozoic basin of the continental margin of China, covering an area of about $770,000 \mathrm{~km}^{2}$ (Figure 1). It includes the East China Sea Shelf Basin in the west and the Okinawa Trough in the east, separated from each other by the Diaoyudao paleo-uplift or Taiwan-Sinzi fold belt. The East China Sea Shelf Basin is divided into a series of sub-basins, separated by basement highs or paleo-uplifts, including the Hupijiao, Haijiao, Yushan, and Yandang paleo-uplifts. The sub-basins can be subdivided into a western group (West Shelf Basin), including the Lishui, Jiaojiang, Fuzhou, Minjiang, Qiantang, and Changjiang sub-basins, and an eastern group (East Shelf Basin), including the Diaobei, Xihu, and Fujiang sub-basins.

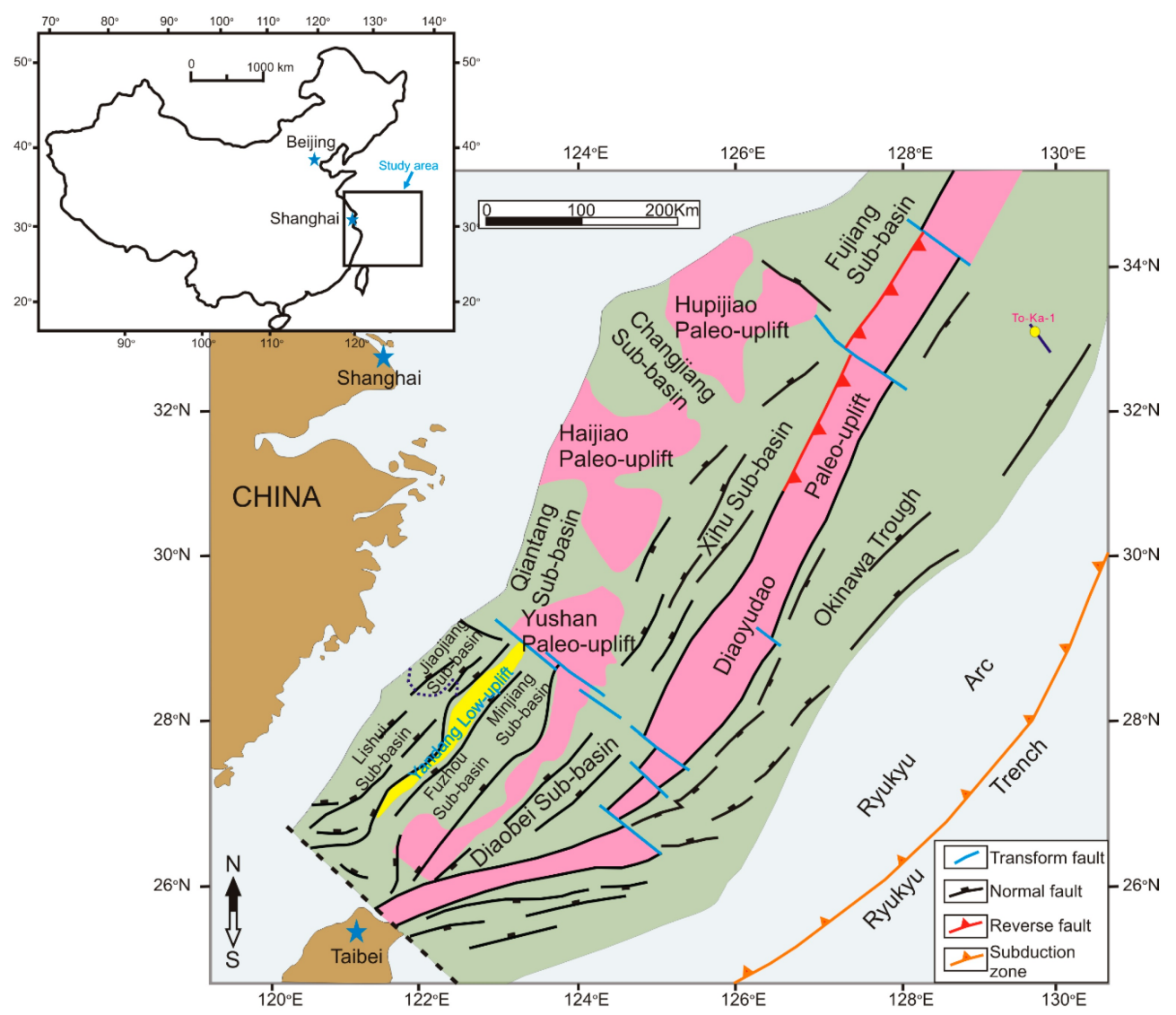

Figure 1. Regional location and sub-units of the East China Sea Basin. Pink represents the paleo-uplift, dark green indicates the sub-basin, yellow represents the local low-uplift, brown represents land area, and light blue represents sea.

\section{Tectonic Evolution}

The East China Sea Basin comprises a complex of back-arc basins located on extended continental crust close to the leading edge of the Eurasian plate. It lies west of the Ryukyu Trench, where the oceanic crust of the Philippine Sea plate 
is subducted below the Eurasian plate (Figure 2).

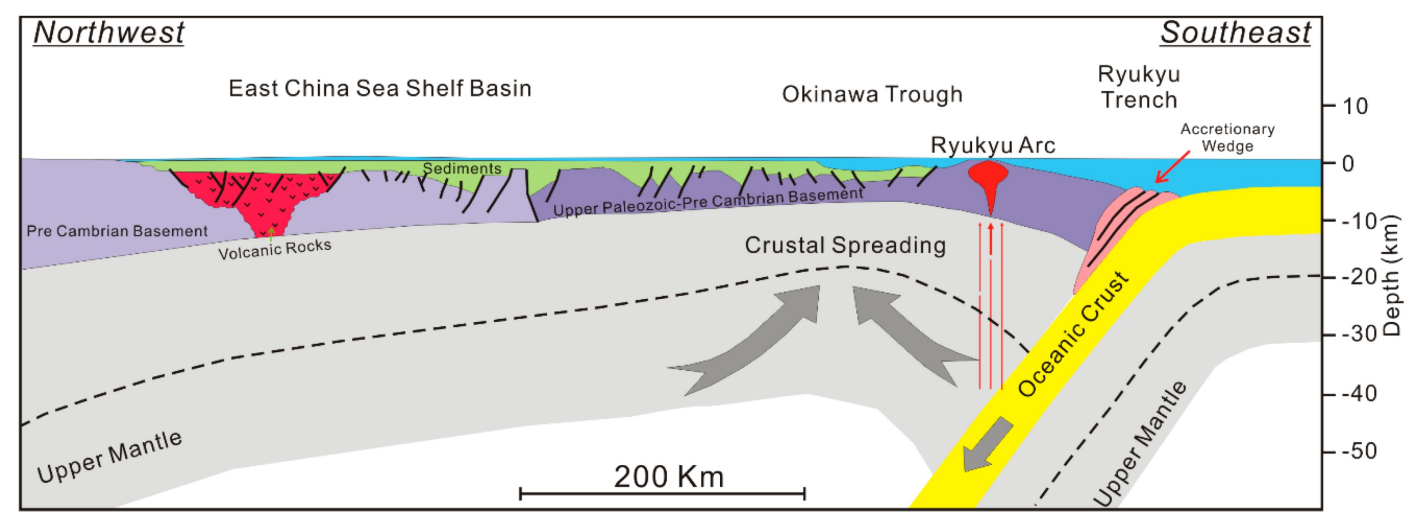

Figure 2. Schematic tectonic cross-section across the East China Sea basins. The East China Sea Shelf Basin and the western part of Okinawa Trough are modified from Reference [1], while the eastern part of the Okinawa Trough and Ryukyu Trench is a schematic. The thicknesses indicated here are approximate.

The tectonic evolution of the East China Sea Basin is still not fully understood. Most of the detailed studies focused on the Okinawa Trough and the Ryukyu Arc. Plate tectonic reconstruction of the Far East generally concentrates around southeast Asia and the southwest Pacific, with the East China Sea being a peripheral area. It is generally accepted that the tectonic evolution of the East China Sea Basin is controlled by the interaction of the Eurasian, Pacific, and Philippine Sea plates; however, the details of the relationship between basin development and the interaction of these three plates remain elusive.

The tectonic evolutionary history of the East China Sea Basin (Figure 3) is described below.

The rift cycle: The East China Sea Basin was formed by faulting during the Late Cretaceous to Paleocene, with the development of half-grabens under (trans)tensional stresses. The initial collision of India with Eurasia resulted in the closure of the Tethys, and the southeastern Eurasia continental margin was pushed eastward along pre-existing major faults. In the east, the Pacific plate changed direction from north to northwest, placing the Eurasian continental margin under a transtensional regime, and the East China Sea Basin probably developed as a complex area of pull-apart rift basins $\left[{ }^{[1]},[2]\right.$. In the West Shelf area, rifting ceased at the end of the Paleocene, but it continued in the East Shelf Basin to encompass the Eocene.

The first post-rift thermal sag cycle: This corresponds to the Eocene in the West Shelf Basin and was brought to an end by a short period of uplift in the Oligocene. Post-rift conditions, on the other hand, did not reach the East Shelf basins until the Oligocene. The collision between India and Eurasia continued during the Late Eocene-Oligocene; however, at the end of Eocene, the Pacific plate changed its relative direction of movement from north-northwest (NNW) to northwest (NW) [ [3] $]$ or NW to west-northwest (WNW) [1] , becoming more perpendicular to the Eurasian continental margin. This is marked in the East China Sea Shelf Basin by the uplift and erosion of the Diaoyudao Paleo-uplift, and an eastward shift of the depo-centers to the Xihu and Diaobei sub-basins.

The inversion cycle: By the end of the Oligocene/Early Miocene period, the northwestward subduction of the Philippine Sea plate affected the southern part of the East China Sea Basin, whereas the northern East China Sea Basin was affected by the Pacific plate subduction. Related inversions were accompanied by a hiatus in the Oligocene in the West Shelf Basin, but only affected the Eastern Shelf in the Late Miocene. By Middle Miocene, the Xihu Sub-basin depositional trend shifted from southeast to northeast. The cause for this shift is not known; however, it is speculated that it is related to the northeastward migration of the Philippine Sea plate, early development in the North Okinawa Trough, and the opening of the Japan Sea to the north. At the end of the Middle Miocene to early Late Miocene, the northwestward subduction of the Philippine Sea plate increased, resulting in the development of the trench-arc-back-arc basin system (Ryukyu Trench-Ryukyu Arc-Okinawa Trough) on the basement, east of the East China Sea Basin. The Xihu Sub-basin underwent compression, and high-relief anticlines were developed mainly on the eastern flank of the sub-basin. This Miocene compression appears to be confined to the Xihu sub-basin. In the Diaobei Sub-basin to the south, there are only a few gentle anticlines with no associated reverse faults [[4]]. 
The second post-rift thermal sag cycle: This cycle commenced in the Miocene in the west and in the Pliocene to the east. Although the Philippine Sea plate subduction beneath the Eurasian plate continued, it appears to have mainly affected the Okinawa Trough (which probably commenced its syn-rift cycle at this time) and the Ryukyu Arc. Most of the rest of the East China Sea Shelf Basin underwent a period of regional sag. The rifting in the Okinawa Trough took place in two phases, and the Pliocene brought about a time of relative calm in terms of extensional tectonics (Figure 3) [[5]].

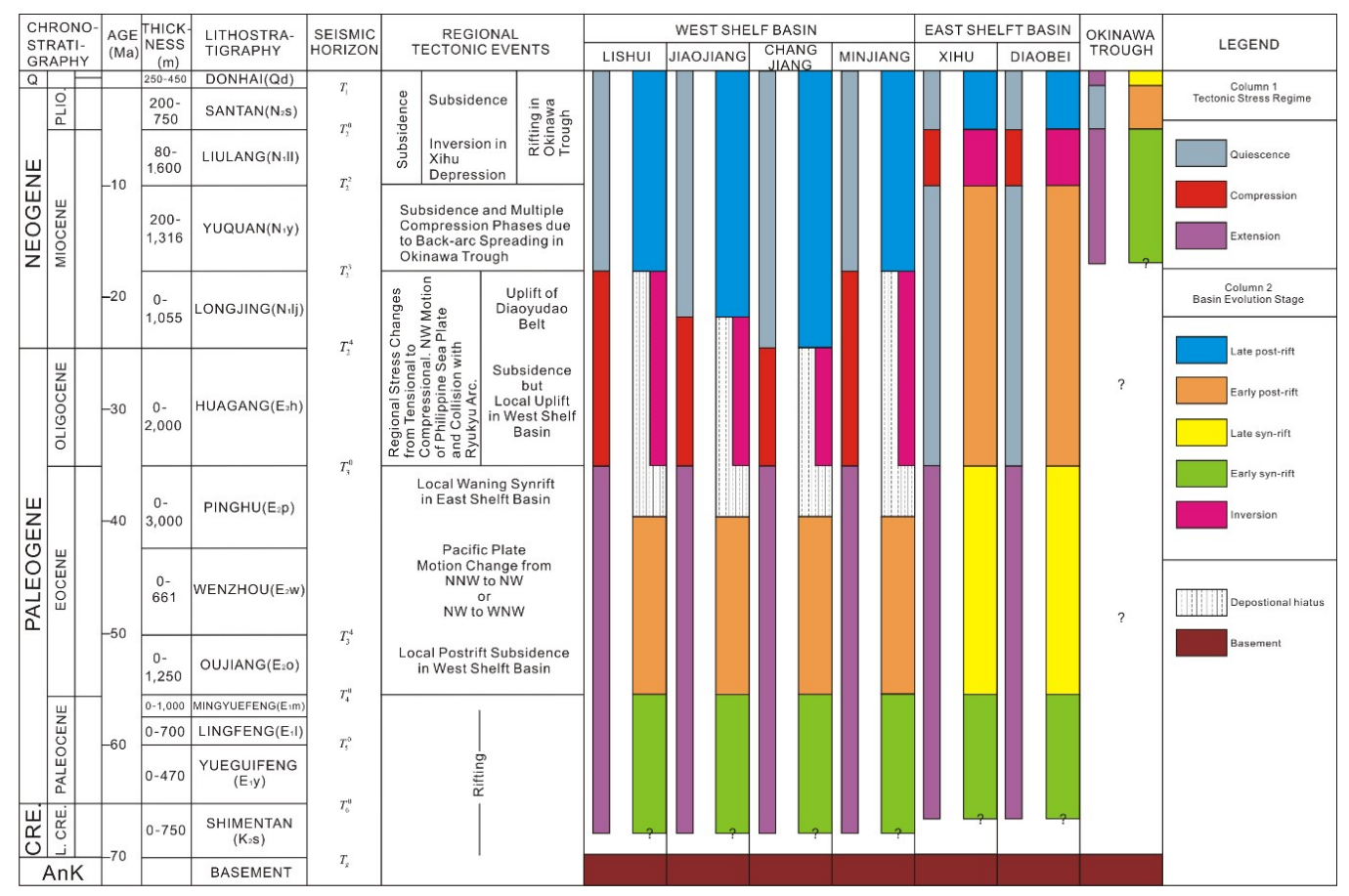

Figure 3. Tectono-stratigraphy of the sub-basins of the East China Sea Basin, showing regional tectonic events and (sub-)basin cycles. For each basin, the columns from left to right show the stress regime and the cycle/stage divisions.

\section{Summary}

The sub-basins of the East China Sea Basin share a common tectonic evolution, from Paleogene syn-rift to Neogene post-rift. They are filled with sediments deposited in environments that evolved from terrestrial lacustrine to transitional into more marine, and they were subject to a series of compressional/inversion events. The only exception is the Okinawa Trough, which is a very young, back-arc sub-basin in which rifting started during the Middle Miocene.

\section{References}

1. Zhou, Z.; Zhao, J.; Yin, P.. Characteristics and tectonic evolution of the East China Sea; Zhu, X., Eds.; Elsevier Science: Amsterdam, The Netherlands, 1989; pp. 165-179.

2. Yang, Z.; The type and basining period of Cenozoic sedimentary basin in East China Sea. Marine Geology \& Quaternary Geology 1992, 2, 3-13, N/A.

3. Jolivet, L.; Huchon, P.; Rangin, C.; Tectonic setting of Western Pacific marginal basins. Tectonophysics 1989, 160, 23-47, 10.1016/0040-1951(89)90382-X.

4. 37. Wang, G.M.; Coward, M.P.; Yuan, W.; Liu, S.; Wang, W.; Fold growth during basin inversion - example from the East China Sea Basin. Geological Society, London, Special Publications 1995, 88, 493-522, 10.1144/gsl.sp.1995.088.01.26.

5. Sibuet, J.C.; Hsu, S.K.; Geodynamics of the Taiwan arc-arc collision. Tectonophysics 1997, 274, 221-251, 10.1016/s00401951(96)00305-8.

\section{Keywords}

East China Sea Basin; Tectonic Evolution

(C) 2019 by the author(s). Distribute under aCreative Commans CC BY license 